Pomáhajúce profesie, roč. 4, č. 1, 2021, 58-65

\title{
OBAVY ZDRAVOTNÍKOV V SÚVISLOSTI S CELOPLOŠNÝM TESTOVANÍM ANTIGÉNOVÝMI TESTAMI
}

\author{
Dana Brázdilová, Iveta Antolová \\ Katedra klinických disciplín a urgentnej medicíny FSVaZ UKF v Nitre \\ dbrazdilova@ukf.sk
}

\begin{abstract}
Abstrakt: Príspevok sa venuje vnímaniu celoplošného (antigénového) testovania zdravotníkmi realizovanom koncom roka 2020 počas pandémie Covid-19 na Slovensku. Tento typ testovania bol pre mnohých prvou skúsenost'ou a preto sa autori zamerali na vnímanie obáv zdravotníkov, ktorí sa na testovaní zúčastnili. Vnímanie obáv a hodnotenie pocitov po absolvovaní testovania autori zist'ovali v kontexte pohlavia a dížky praxe. Zistili, že vplyv pohlavia na vnímanie obáv má iba miernu štatistickú významnost' a u dížky praxe na prežívanie obáv sa štatistický významný rozdiel nepreukázal. Po absolvovaní testovania boli najpočetnejšie zastúpený pocit spokojnosti s rozhodnutím testovania sa zúčastnit'.
\end{abstract}

Kl'účové slová: Pandémia Covid-19. Antigénové testovanie. Obava. Výter z nosohltana.

\section{1 ÚVOD}

Svetová zdravotnícka organizácia (WHO) vyhlásila 11. marca 2020 pandémiu koronavírusu s t’ažkým akútnym respiračným syndrómom (SARS-CoV-2). Pandémia COVID-19 je výzvou pre verejné zdravie, ktorá stavia zdravotnícke systémy do vel'mi zranitel'nej situácie (Vašut, Vranová, 2020). V Európe viedlo rýchle šírenie vírusu vlády v niektorých krajinách k vyhláseniu núdzového stavu, zavedeniu úplných alebo čiastočných obmedzení zákazu vychádzania pre ich obyvatel'stvo, čiastočnému uzavretiu hraníc a zastaveniu výrobných a vzdelávacích činností ako základných opatrení (González-Gill et al., 2021).

Vláda SR sa ako jediná rozhodla realizovat' celoplošné testovanie občanov prostredníctvom antigénových testov. Nakol'ko šírenie pandémie sa v tom čase javilo ako nekontrolovatel'né, podmienkou bolo aby sa čo najväčší počet obyvatel'ov na testovaní zúčastnil. Testovanie bolo dobrovol'né a mohli sa na ňom zúčastnit' všetci starší ako desat' rokov. Testovanie sa neodporúčalo len tým, ktorí mali nad 65 rokov a trávili väčšinu času vo svojich domovoch, prípadne všetkým obyvatel'om so zníženou mobilitou či zdravotnými obmedzeniami, ktorí sa prirodzene vyhýbajú sociálnemu kontaktu. Tí, ktorí sa ho nezúčastnili však mali isté obmedzenia. V prípade, že sa nachádzali v tzv. „červenom okrese“, mohli sa bez sankcie dat' otestovat’ v druhom kole testovania. Za cestu na antigénový test, ako porušenie zákazu vychádzania v tomto prípade sankcionovaní neboli. Cesta na antigénový test $\mathrm{v}$ rámci plošného testovania totiž spadala pod neodkladné vyšetrenie, na ktorú sa výnimka zo zákazu vychádzania vzt’ahuje. Toto testovanie realizovali (za stanovených podmienok) zdravotníci po celej krajine. Prvé testovanie prebiehalo v dňoch 30.10 a 1.11.2020 od 7,00 - 22,00 hod. Počas nasledujúceho víkendu 7. a 8. novembra 2020 sa uskutočnilo plošné testovanie obyvatel'ov v rámci 45 okresov, kde počet l'udí s pozitívnym výsledkom testov dosiahol $\mathrm{v}$ rámci celoplošného testovania obyvatel'ov hranicu $0,7 \%$ a viac. $\mathrm{V}$ prvom kole testovania bolo celkovo 3625332 otestovaných a 38359 z toho infekčných (www.somzodpovedny.sk).

Konzílium odborníkov v tomto čase však celoplošné testovanie neodporučilo. Konzílium v stanovisku, ktoré poskytlo vtedajšiemu ministrovi zdravotníctva Marekovi Krajčimu, prišlo s 
návrhom, ako efektívne využit' antigény. Odporúčali cielené a pravidelné testovanie rizikových skupín (TASR, 2020).

Ako sa neskôr vyjadrila epidemiologička Bražinová: „plošné testovanie na celom Slovensku nie je podl'a mňa v tejto chvíli ani dobrý, ani realizovatel'ný nápad. Organizovat' plošné testovanie v situácii, ked' je potrebné minimalizovat' stretávanie l'udí, je nezodpovedné, ked'že vieme, že sa budú l'udia hromadit’ a čakat' pri odberných miestach“ (Folentová, Barcíková, 2021, s. 1).

Situácia bola koncom uplynulého roka bola na Slovenku, podobne ako aj v okolitých krajinách, vel'mi vážna a na zdravotníkov bol vyvíjaný tlak nielen v súvislosti s nárastom prípadov a počtu hospitalizovaných po celom Slovensku, ale aj na potrebe participácie na testovaní a pripravovanom očkovaní. Duševná pohoda zdravotníckych pracovníkov pracujúcich v prvej línii je v čase pandémie ohrozená tým, že predstavuje stredne vysokú úroveň úzkosti, depresie, nervozity a nespavosti a v menšej miere stresu (García-Iglesias et al., 2020). Podl'a autorov (Zhang et al, 2020) zdravotník v prvej línii bol definovaný ako pracovník priamo zapojený do prevencie a liečby COVID-19 a priamo $\mathrm{v}$ kontakte s potvrdenými alebo podozrivými prípadmi prostredníctvom príjmu pacienta, skríningu, inšpekcie, testovania, prepravy, liečby, ošetrovatel'stva, odberu vzoriek, detekcie patogénov, patologického vyšetrenia alebo patologickej anatómie zdravotníckeho a zdravotníckeho personálu.

Na základe uvedeného môžeme zdravotníkov participujúcich na celoplošnom testovaní zaradit’ do kategórie zdravotníkov v prvej línii (El-Hage et al., 2020). Rastúci počet výskumov ukazuje, že únava zdravotníckych pracovníkov zvyšuje riziko chýb v starostlivosti o pacientov a zranení samotných zdravotníkov (Zhang et al, 2020). V ich prieskume realizovanom v provincii Henane, ktorá sa geograficky nachádza v blízkosti Wu-chanu v Číne sa za prepracovaných považovali zdravotníci, ak počas predchádzajúceho týždňa pracovali v priemere viac ako 8 hodín denne. V tomto kontexte nás zaujímalo ako samotní zdravotníci vnímajú potrebu ich participácie na testovaní. Zamerali sme s na to či vnímajú obavy v súvislosti s testovaním a ako hodnotia tieto obavy po testovaní.

Na základe dôkladnej analýzy problematiky sme stanovili ciele nášho príspevku. Hlavnou témou je vnímanie, resp. prežívanie obáv pred testovaním a hodnotenie po absolvovaní testovania. Za klúčový aspekt považujeme prežívanie obáv vo vzt’ahu k pohlaviu a dížke praxe. Na základe uvedeného sme si stanovili nasledovné otázky pre výskum:

Výskumná otázka č. 1: Sú obavy zdravotníkov spojené s celoplošným testovaním rozdielne z hl'adiska pohlavia?

Výskumná otázka č. 2: Sú obavy zdravotníkov spojené s celoplošným testovaním rozdielne z hl'adiska dížky praxe?

\section{METóDY}

Na testovaní realizovali zdravotníci viacerých profesií (sestry, záchranári ako aj študenti zdravotníckych smerov) odber (ster) z nosohltana. Zdravotníci robili odber vosobných ochranných pomôcok (OOP) so stanoveným intervalom na prestávku. OOP zahŕňali celotelovú kombinézu (vrátane špeciálnej ochrannej obuvi, či návlekov na obuv), tvárové ochranné štíty, tvárové masky a polomasky s filtrom rôzne ochrany a respirátory rôzne kategórie, typu a miery ochrany. Zdravotník musel v OOP vydržat' najmenej 4 hodiny bez prestávky. Vyzliekanie bolo realizované po vonkajšej dezinfekcii dezinfekčným prostriedkom spôsobom aby nedošlo ku kontaminácii. Samotné obliekanie a vyzliekanie si vyžadovalo istú dávku zručnosti. Mnohí zdravotníci sa s týmito OOP stretli po prvý krát. Zdravotníci boli členení do kategórií podl’a toho aká bola ich úloha v súvislosti s testovaním. Odberové miesta boli pod gesciou obce, ktorá 
v spolupráci HaZZ a PZ organizovala jednotlivých záujemcov o testovanie. Situácia na odberových miestach bola rozdielna v súvislosti s vel'kost'ou obce. Vo väčších mestách boli odberové miesta vol'ne prístupné (bez časového harmonogramu pre občanov), v menších obciach si starostovia obce vytvárali časové poradovníky najčastejšie podl'a ulíc, resp. čísla domov.

\subsection{Metódy zberu dát}

Východiskovými metódami pre získavanie informácií v rámci výskumu boli obsahová analýza dokumentov, ktorá je metódou na hodnotenie informačnej náplne textu. Zber dát bol realizovaný formou neštandardizovaného dotazníka vlastnej konštrukcie. Dotazník obsahoval dvadsat' zatvorených a štyri otvorené otázky. Dotazník bol vytvorený v službe Survio (survio.com). Dotazník bol distribuovaný online a jeho vypíňanie prebiehalo v mesiacoch november - december 2020.

\subsection{Výberový súbor}

Súbor tvorilo 80 respondentov, ktorí sa zúčastnili celoplošného testovania vo viacerých etapách v pozícii zdravotníkov kategórie A a B. Z tohto počtu bolo 59 (73,8\%) žien a 21 (26,3\%) mužov. Z hl'adiska dížky praxe prevažovali zdravotníci s kratšou praxou ako 5 rokov 52 (65\%) respondentov. Dĺžku praxe 5 a viac rokov malo 28 respondentov (35\%). Z hladiska profesie najväčšiu skupinu tvorilo študenti zdravotníckych odborov štúdia - 50 respondentov $(62,5 \%)$. Druhou najpočetnejšou skupinou boli sestry 10 respondentov (12,5\%). Z hl'adiska vzdelania najpočetnejšiu skupinu (58,8\%) tvorili absolventi Stredných zdravotníckych škôl, teda respondenti s ukončeným stredoškolským vzdelaním s maturitou. Ukončené VŠ vzdelanie I. alebo II. stupňa malo 16 respondentov (20\%). V súbore prevažovali respondenti $(61,3 \%)$, ktorí si zvolili odberové miesto v súvislosti so svojim bydliskom. I. etapy testovania (31.10 a 1.11.2020) sa zúčastnilo takmer $90 \%$ respondentov. II. etapy (7. a 8.11.2020) sa zúčastnilo viac ako 56\% respondentov súboru.

\subsection{Výskumný plán}

Výskum pre našu prácu sme realizovali v časovom horizonte mesiacov november - december 2020. V mesiaci október 2020 sa členka autorského kolektívu zúčastnila pilotného kola testovania na Orave. $\mathrm{Na}$ základe získaných informácií spojených stestovaním sme v vypracovali neštandardizovaný dotazník, ktorý sme po ukončení I. a II. etapy testovania (november 2020) distribuovali elektronicky. Zber dát bol ukončený začiatkom decembra 2020. Získané dáta sme následne vyhodnotili a kvantitatívne spracovali do grafickej podoby. Išlo o kvantitatívny prierezový výskumný dizajn

\subsection{Metódy analýzy dát}

Pre skúmanie stanovených výskumných otázok sme použili početnosti (n), relatívne početnosti (\%), priemerné hodnoty (M) a smerodajné odchýlky (SD). Pre štatistické hodnotenie sme použili Chí-kvadrát test homogenity $\left(\chi^{2}\right)$ a Fisherovu Analýzu rozptylu (F).

\section{VÝSLEDKY}

V nasledujúcej časti ponúkame výsledky získaných dát po vyhodnotení dotazníkového šetrenia. V prvej časti prezentujeme výsledky zamerané na zistenie úrovne obáv spojených s priebehom testovania ako aj hodnotenie testovania po jeho realizovaní. Následne tieto premenné hodnotíme s hl'adiska rozdielov pohlavia a dížky praxe našich respondentov. 


\subsection{Analýza obáv spojených s testovaním}

Celoplošné testovanie bolo pre mnohých zdravotníkov stresujúce a spojené s obavami ako bude testovanie na odberových miestach prebiehat' a či budú vediet' pracovat' v OOP v stanovených intervaloch. Ďalším dôvodom obáv mohlo byt’ riziko nakazenia alebo nespokojnost' samotných obyvatel'ov, ktorí testovanie podstúpili.

Tabul'ka 1. Obavy z hl'adiska pohlavia

\begin{tabular}{|c|c|c|c|c|c|c|}
\hline & \multicolumn{2}{|c|}{ muži $(n=21)$} & \multicolumn{2}{|c|}{ ženy $(n=59)$} & \multirow[b]{2}{*}{$\mathrm{F}$} & \multirow[b]{2}{*}{$\mathrm{p}$} \\
\hline & M & SD & M & SD & & \\
\hline $\begin{array}{l}\text { či zvládnem, resp. vydržím testovanie } \\
\text { (ochranný odev, toaleta, jedlo, pitie) }\end{array}$ & 0,19 & 0,40 & 0,39 & 0,49 & 2,78 & 0,099 \\
\hline $\begin{array}{l}\text { že nebudem vediet' (chýbajúce skúsenosti s } \\
\text { týmto typom testov) }\end{array}$ & 0,10 & 0,30 & 0,31 & 0,46 & 3,72 & 0,058 \\
\hline že sa pomýlim pri stanovení výsledku & 0,05 & 0,22 & 0,14 & 0,35 & 1,19 & 0,279 \\
\hline $\begin{array}{l}\text { obával som sa, že môžem spôsobit' poranenie } \\
\text { pri odbere }\end{array}$ & 0,05 & 0,22 & 0,14 & 0,35 & 1,19 & 0,279 \\
\hline obával som sa, že sa nakazím & 0,19 & 0,40 & 0,32 & 0,47 & 1,30 & 0,258 \\
\hline že testovanie bude chaotické, nekoordinované & 0,19 & 0,40 & 0,36 & 0,48 & 1,97 & 0,164 \\
\hline že občania budú podráždení z dlhého čakania & 0,14 & 0,36 & 0,37 & 0,49 & 3,91 & 0,052 \\
\hline
\end{tabular}

Zistili sme, že na hranici štatistickej významnosti sa ukazujú rozdiely vo vnímaní obáv z hl'adiska pohlavia v dvoch položkách obe na strane žien. Sú to obavy z podráždenia občanov v prípade dlhého čakania $(\mathrm{p}=0,052)$ a hranične na obave, že respondenti nebudú vediet' pracovat' $\mathrm{s}$ testami, nakol'ko nemali skúsenost's týmto typom testov $(\mathrm{p}=0,058)$.

Tabul'ka 2. Obavy zdravotníkov z hl'adiska dížky praxe

\begin{tabular}{|c|c|c|c|c|c|c|}
\hline & \multicolumn{2}{|c|}{$\begin{array}{l}\text { do } 5 \text { rokov } \\
(\mathrm{n}=52)\end{array}$} & \multicolumn{2}{|c|}{$\begin{array}{l}\text { nad } 5 \text { rokov } \\
(\mathrm{n}=28)\end{array}$} & \multirow[b]{2}{*}{$\mathrm{F}$} & \multirow[b]{2}{*}{$\mathrm{p}$} \\
\hline & $\mathrm{M}$ & SD & $\mathrm{M}$ & SD & & \\
\hline $\begin{array}{l}\text { či zvládnem, resp. vydržím testovanie } \\
\text { (ochranný odev, toaleta, jedlo, pitie) }\end{array}$ & 0,35 & 0,48 & 0,32 & 0,49 & 0,05 & 0,826 \\
\hline $\begin{array}{l}\text { že nebudem vediet' (chýbajúce skúsenosti s } \\
\text { týmto typom testov) }\end{array}$ & 0,27 & 0,45 & 0,21 & 0,46 & 0,29 & 0,594 \\
\hline že sa pomýlim pri stanovení výsledku & 0,12 & 0,32 & 0,14 & 0,35 & 0,01 & 0,913 \\
\hline $\begin{array}{l}\text { obával som sa, že môžem spôsobit' poranenie } \\
\text { pri odbere }\end{array}$ & 0,12 & 0,32 & 0,14 & 0,35 & 0,01 & 0,913 \\
\hline obával som sa, že sa nakazím & 0,35 & 0,48 & 0,32 & 0,47 & 2,51 & 0,117 \\
\hline že testovanie bude chaotické, nekoordinované & 0,33 & 0,47 & 0,36 & 0,48 & 0,14 & 0,709 \\
\hline že občania budú podráždení z dlhého čakania & 0,27 & 0,45 & 0,37 & 0,49 & 1,28 & 0,261 \\
\hline
\end{tabular}

Zistili sme, že štatisticky významné rozdiely vo vnímaní obáv u zdravotníkov z hl'adiska dížky praxe sa nepreukázali. 


\subsection{Analýza hodnotenia prežívania po testovaní}

Tabul'ka 3. Hodnotenie testovania po jeho absolvovaní z hl'adiska pohlavia

\begin{tabular}{|c|c|c|c|c|c|c|}
\hline \multirow[t]{2}{*}{ Možnosti/pohlavie } & \multicolumn{2}{|c|}{ muži } & \multicolumn{2}{|r|}{ ženy } & \multicolumn{2}{|c|}{ Spolu } \\
\hline & $\mathrm{n}$ & $\%$ & $\mathrm{n}$ & $\%$ & $\mathrm{n}$ & $\%$ \\
\hline $\begin{array}{l}\text { bol som spokojný, že sa moje obavy } \\
\text { nenaplnili }\end{array}$ & 2 & $9,50 \%$ & 5 & $8,50 \%$ & 7 & $8,80 \%$ \\
\hline $\begin{array}{l}\text { bol som spokojný, že som sa rozhodol } \\
\text { správne }\end{array}$ & 12 & $57,10 \%$ & 25 & $42,40 \%$ & 37 & $46,30 \%$ \\
\hline cítil som sa vel'mi unavený, resp. zničený & 3 & $14,30 \%$ & 21 & $35,60 \%$ & 24 & $30,00 \%$ \\
\hline neriešil som svoje pocity & 3 & $14,30 \%$ & 7 & $11,90 \%$ & 10 & $12,50 \%$ \\
\hline $\begin{array}{l}\text { bol som unavený/á ale zároveň št'astný/á z } \\
\text { toho že som mohol/la pomôct' }\end{array}$ & 0 & $0,00 \%$ & 1 & $1,70 \%$ & 1 & $1,30 \%$ \\
\hline $\begin{array}{l}\text { bol som vel'mi unavený, ale rád, že som } \\
\text { pomohol pomôct' }\end{array}$ & 1 & $4,80 \%$ & 0 & $0,00 \%$ & 1 & $1,30 \%$ \\
\hline Spolu & 1 & $100,00 \%$ & 59 & $100,00 \%$ & 80 & $100,00 \%$ \\
\hline
\end{tabular}

Zistili sme, že po testovaní bol u mužov najviac zastúpený pocit spokojnosti so správnym rozhodnutím testovania sa zúčastnit' ( $\mathrm{r}=57,10 \%)$. Rovnako aj u žien bol tento pocit zastúpený v najvyššom počte $(\mathrm{r}=42,40 \%)$. Druhým najviac zastúpeným pocitom bol u žien unavenost', resp. zničenost' ( $\mathrm{r}=35,60 \%)$. V hodnotení testovania po jeho absolvovaní nie je štatisticky významný rozdiel medzi mužmi a ženami $\left(\chi^{2}(5)=6,33 ; p=0,275\right)$.

Tabul'ka 4 Hodnotenie prežívania testovania po jeho absolvovaní z hl'adiska dížky praxe Možnosti/prax do 5 rokov nad 5 rokov Spolu

\begin{tabular}{|c|c|c|c|c|c|c|}
\hline & & & & & & \\
\hline & $\mathrm{n}$ & $\%$ & $\mathrm{n}$ & $\%$ & $\mathrm{n}$ & $\%$ \\
\hline $\begin{array}{l}\text { bol som spokojný, že sa moje obavy } \\
\text { nenaplnili }\end{array}$ & 5 & $9,60 \%$ & 2 & $1,10 \%$ & 7 & $8,80 \%$ \\
\hline $\begin{array}{l}\text { bol som spokojný, že som sa rozhodol } \\
\text { správne }\end{array}$ & 27 & $51,90 \%$ & 10 & $35,70 \%$ & 37 & $46,30 \%$ \\
\hline cítil som sa vel'mi unavený, resp. zničený & 14 & $26,90 \%$ & 10 & $35,70 \%$ & 24 & $30,00 \%$ \\
\hline neriešil som svoje pocity & 5 & $9,60 \%$ & 5 & $17,90 \%$ & 10 & $12,50 \%$ \\
\hline $\begin{array}{l}\text { bol som unavený/á ale zároveň št'astný/á z } \\
\text { toho že som mohol/la pomôct' }\end{array}$ & 1 & $1,90 \%$ & 0 & $0,00 \%$ & 1 & $1,30 \%$ \\
\hline $\begin{array}{l}\text { bol som vel'mi unavený, ale rád, že som } \\
\text { pomohol pomôct' }\end{array}$ & 0 & $0,00 \%$ & 1 & $3,60 \%$ & 1 & $1,30 \%$ \\
\hline Spolu & 52 & $100,00 \%$ & 28 & $100,00 \%$ & 80 & $100,00 \%$ \\
\hline
\end{tabular}

Z hl'adiska dížky praxe je rovnako z celkového počtu ako aj počtu odpovedív oboch kategóriách do 5 a nad 5 rokov praxe najviac zastúpený pocit spokojnosti s rozhodnutím zúčastnit' sa testovania. V hodnotení testovania po jeho absolvovaní nie je štatisticky významný rozdiel z hl'adiska dížky $\operatorname{praxe}\left(\chi^{2}(5)=5,01 ; \mathrm{p}=0,414\right)$. 


\section{DISKUSIA}

Rok 2020 zostane pre väčšinu l'udskej populácie nerozlučne spojený s pandémiou ochorenia covid19, ktorý je spôsobený vírusom SARS-CoV-2. K 1. 1. 2021 bolo celosvetovo hlásených takmer 84 miliónov potvrdených prípadov a viac ako 1,8 milióna úmrtí. Tento počet stále rástol. Hoci intenzívne protiepidemické opatrenia silne ovplyvnili spoločenský život, vzdelávací systém i ekonomiku vo väčšine sveta, ich výsledkom zatial' vždy bolo len prechodné spomalenie šírenia infekcie. Po zmiernenie obmedzenia doteraz zakaždým nasledovalo d'alšie šírenia vírusu v populácii. Epidemiologické a virologické štúdie WHO predpokladajú, že sa infekcia šíri najmä od symptomatických nakazených na ostatných pomocou kvapôčok a aerosólu z dýchacích ciest, priamym kontaktom $s$ infikovanou osobou alebo kontaktom s kontaminovanými predmetmi /povrchy. Najväčšia koncentrácia vírusu boli dokázané u infikovaných osôb v horných dýchacích cestách (nos a krk) v prvých 3 dňoch od vzniku príznakov. Za asymptomatické sú považované osoby, u ktorých sa nevyvinú žiadnej z klinických príznakov ochorenia (Křupka et all, 2021).

V epidémiách vysoko infekčných chorôb, akou pandémia ochorenia Covid-19 bez pochýb je, sú zdravotnícki pracovníci $\mathrm{v}$ rámci osobného kontaktu s biologickým materiálom infikovaných pacientov vystavení ovel'a väčšiemu riziku infekcie než bežná populácia. Na ochranu zdravotníckych pracovníkov sú definované osobné ochranné pomôcky (OOP), ktoré znižujú riziko nákazy zakrytím exponovaných častí tela. Je faktom, že systematicky bolo k používaniu špecifických OOP vyškolilo len málo zdravotníckych pracovníkov, ktorí boli pripravovaní na kontakt s pacientmi s vysoko infekčným ochorením. Bežne to boli iba posádky Biohazard tímov zdravotníckych záchranných zložiek, príslušníkov hasičských zborov, alebo zdravotníckych pracovníkov pracujúcich na infekčných oddeleniach (Saibertová, Pokorná, 2020). Platilo to aj na účastníkov celoplošného testovania. Bolo na účastníkovi ako sa na použitie spomínaných pomôcok pripravil. Či už skúšobným obliekaním, resp. vyzliekaním, alebo sledovaním náučných videí, čítaním odborných príspevkov. Pre mnohých zúčastnených bolo testovanie prvou príležitostou dané pomôcky vyskúšat'. Rovnako to bolo aj s postupom práce pri testovaní antigénovými testami. Preto bolo na mieste zistit', či zdravotníci, ktorí sa testovania zúčastnili nepocit'ujú obavy spojené s testovaním.

Prvá výskumná otázka bola zameraná na vnímanie obáv zdravotníkov v súvislosti s testovaním. Zamerali sme sa na zistenie rozdielov $\mathrm{z}$ hl'adiska pohlavia. $\mathrm{Z}$ výsledkov vyplýva, že rozdiely vo vnímaní obáv z hl'adiska pohlavia sa ukázali iba v dvoch položkách obe na strane žien, na hranici štatistickej významnosti. Sú to obavy z podráždenia občanov v prípade dlhého čakania $(\mathrm{p}=0,052)$ a hranične na obave, že respondenti nebudú vediet' pracovat's testami, nakol'ko nemali skúsenost' $\mathrm{s}$ týmto typom testov ( $\mathrm{p}=0,058)$. Celková hodnota vnímania obáv bola u mužov nízka.

Následne v druhej výskumnej otázke sme problematiku obáv hodnotili z hl’adiska dížky praxe. Z výsledkov vyplýva, že štatisticky významný rozdiel sa v tejto skúmanej rovine nepotvrdil.

Následne sme chceli zistit' aké pocity prežívali respondenti nášho súboru po absolvovaní testovania. Zistili sme, že najpočetnejšiu skupinu tvoria respondenti, ktorí v celkovom hodnotení vyjadrili spokojnost's rozhodnutím testovania sa zúčastnit'. V súvislosti s obavami pred testovaním je priaznivým výsledkom, že 8,80\% respondentov po absolvovaní testovania vyjadrilo spokojnost', že sa ich obavy nenaplnili.

\section{ZÁVER}

V nedávnej minulosti sme sa nachádzali v historicky najdlhšie trvajúcej mimoriadnej udalosti. To podmienilo nárast duševných t’ažkostí v porovnaní s dobou pred pandémiou.V Českej republike sa 
ide o desat'percentný nárast (podl'a údajov Národního ústavu duševního zdraví), v zahraničí aj vyššie (Buchtová, Hrušková Kusnieriková, 2021). Predpokladáme, že na Slovensku je to podobné. Táto situácia sa však môže kedykol'vek zopakovat'. Tlak vyvíjaný nielen na zdravotníkov bude aj v budúcnosti narastat'. Preto by sme sa mali poučit' a na odborníkmi avizovanú nasledujúcu vlnu by sme sa mali adekvátne pripravit'.

Celoplošné testovanie sa v skutočnosti ukázalo ako neefektívne, dokonca niektorými odborníkmi prezentované ako rizikové. Napriek tejto skutočnosti sa ukázalo, že je nevyhnutné pristúpit’ ak k nepopulárnym obmedzeniam. Za účast' na celoplošnom testovaní patrí vel'ká vd'aka za účast' zdravotníkom. Netreba však zabúdat' aj na všetkých ostatných administratívnych pracovníkov, dobrovol'níkov aj príslušníkov ozbrojených síl, policajného zboru a hasičského a záchranného zboru a samospráv, ktorí podporili toto celoplošné testovanie.

\section{LITERATÚRA}

Buchtová, V., \& Hrušková Kusnieriková, A. (2021). Doba covidová - stresová - doporučení, jak si s ní poradit. Psychické stavy provázející SARS-CoV-2. Solen, 22(1), 6-11. doi: 10.36290/psy.2021.001

El-Hage, W., Hingray, C., Lemogne, C., Yrondi, A., Brunault, P., Bienvenu, T., ... Aouizerateh, B. (2020). Health professionals facing the coronavirus disease 2019 (COVID-19) pandemic: What are the mental health risks? Encephale, 46(3), 73-80.

Folentová, V., \& Barcíková, M. (2021). Celoplošné testovanie je nezodpovedným plytvaním. Prečo ho nerobia iné vlády? Denník $N$. [online] [citované 2021-06-08] dostupné na: https://dennikn.sk/2222044/celoplosne-testovanie-je-nezodpovednym-plytvanim-preco-honerobia-ine-vlady-odbornici-a-politici-hovoria-ako-bojovat-s-pandemiou-anketa/

García-Inglesias, J., J., Gómez-Salgado, J., Fagundo-Rivera, J., Romero-Martín, M., Ortega-Moreno, M., \& Navarro-Abal, Y. (2021). Predictive factors for burnout and work engagement levels among doctors and nurses: a systematic review. Revista española de salud pública 5;95:e202104046.

González-Gil, M., T., González-Blázquez, C., Parro-Moreno, A., I., Pedraz-Marcos, A., Palmar-Santos, A., Otero-García, L. ... Oter-Quintana, C. (2021). Nurses' perceptions and demands regarding COVID19 care delivery in critical care units and hospital emergency services. Intensive and Critical Care Nursing, 62, 102966.

Křupka, M., Kosztyu, P., Račanský, M., Schovánek, J., Sloupenská, K., Strojil, J., Raška, M. (2021). Možnosti a principy vakcinace proti covidu-19. Praktické lékárenství, 17(1), 7-13.

Saibertová, S., Pokorná, A. (2021). Nejčastější chyby při používání osobních ochranných pomůcek. Medicína pro praxi, 18(1), 75-78.

TASR. (2020). Matovičove plány dostali trhlinu. Konzílium sa postavilo proti d’alšiemu plošnému testovaniu. Hospodárske noviny. [online] [citované 2021-06-08] dostupné na: https://slovensko.hnonline.sk/2253771-konzilium-odbornikov-neodporuca-dalsie-kolaplosneho-testovania-vysvetluje-svoje-dovody

Vašut, K., Vranová, V. (2020). Koronavirus COVID-19. Via practica, 17(4), 185-188.

Zhang, M., Zhou, M., Tang, F., Wang., Y., Nie, H., Zhang, L., You, G. (2020). Knowledge, attitude, and practice regarding COVID-19 among healthcare workers in Henan, China. Journal of Hospital Infection, 105(2), 183-187.

https://www.somzodpovedny.sk/ 
Pomáhajúce profesie, roč. 4, č. 1, 2021, 58-65

\section{CONCERNS OF HEALTHCARE WORKERS CONCERNING OVERALL TESTING WITH ANTIGEN TESTS}

Abstract: The paper deals with the perception of nationwide (antigen) testing by healthcare professionals carried out at the end of 2020 during the Covid-19 pandemic in Slovakia. This type of testing was the first experience for many, so the authors focused on perceiving the concerns of healthcare professionals who participated in the testing. The authors investigated the perception of concerns and the evaluation of feelings after testing in the context of gender and length of practice. The minor effect of gender on the perception of concerns was found and there was no statistically significant difference in the length of practice according to their concerns. After completing the testing, the most numerous were the feeling of satisfaction with the decision to participate in the testing.

Keywords: Covid-19 pandemic. Antigen testing. Concerns. Nasopharyngeal swab. 